\title{
Weekend Effect pada Indeks Harga Saham Gabungan (IHSG) Indonesia Pasca Krisis
}

\author{
Kevin Chanry, Wilson \\ Fakultas Manajemen Keuangan Universitas Prasetiya Mulya
}

\begin{abstract}
Weekend effect is a form of inefficiency that makes stock returns are not random (predictable) and repetitive which is against the efficient market theory by Fama (1991). This study aims to encourage stock investor knowledge about these anomalies, and act more measurably, so that a more efficient market can be achieved. This study uses a regression method that is looking for a significant value between days against the daily return index with the aim of finding a trading pattern on a particular day, especially on Monday and Friday. As a result, the weekend effect occurs during the postcrisis impact on the real sector, in other words affect the performance of the company's stock returns as a whole so that the global financial crisis which is the postcrisis 2007-2008 has a negative statement on the weekend effect.
\end{abstract}

Keywords: Weekend Effect, Postcrisis, Return, Efficient Market, Anomaly Market

\begin{abstract}
ABSTRAK
Weekend effect merupakan bentuk ketidakefisienan yang membuat return saham menjadi tidak random (predictable) dan berulang yang mana menentang teori pasar efisien oleh Fama (1991). Penelitian ini bertujuan untuk mendorong pengetahuan investor saham mengenai anomali ini, dan bertindak lebih terukur, sehingga pasar yang lebih efisien dapat tercapai. Penelitian ini menggunakan metode regresi yaitu mencari nilai signifikansi antara hari terhadap daily return index dengan tujuan mencari pola perdagangan pada hari tertentu khususnya pada hari Senin dan Jumat. Hasilnya, weekend effect terjadi saat pascakrisis yang berdampak pada sektor riil, dengan kata lain mempengaruhi performa return saham perusahaan secara keseluruhan sehingga krisis keuangan global yaitu pascakrisis 2007-2008 memiliki pernyataan negatif terhadap weekend effect.
\end{abstract}

Kata kunci: Weekend Effect, Pascakrisis, Imbal Hasil, Pasar Efisien, Anomali Market 


\section{PENDAHULUAN}

Fama (1991) mengemukakan Efficient Market Hypothesis (EMH) yang menjelaskan bahwa harga saham yang beredar di pasar modal memiliki nilai wajar sesuai dengan informasi yang beredar di masyarakat. Informasi yang dimaksud tentu adalah suatu informasi yang tidak dapat diprediksi oleh investor dan memiliki dampak terhadap economic value sebuah perusahaan. Dalam pasar yang efisien, seorang investor tidak dapat melakukan technical analysis terhadap suatu saham karena setiap informasi yang beredar dianalisa berdasarkan fundamental yang berpengaruh secara langsung terhadap saham perusahaan tersebut. Karena harga saham yang beredar di pasar mencerminkan fundamentalnya, maka sebuah saham tidak akan bisa dibeli dengan harga yang undervalued atau di bawah harga wajarnya.

Hipotesis mengenai pasar efisien ini banyak menimbulkan pro dan kontra dalam beberapa jurnal. Pihak kontra menyebutkan bahwa pasar efisien tidak akan pernah terjadi karena untuk mencapai suatu kondisi pasar efisien, sebuah informasi harus memenuhi persyaratan transparency information (Biais, 1993). Transparency information tersebut menjadi elemen terpenting dalam melakukan trading dan investing dalam market (Easley \& O'Hara, 1995). Pertama, emiten wajib memberikan seluruh informasi terkait perusahaannya. Kedua, informasi yang disampaikan harus disertai dengan waktu yang sesuai dan ketiga yaitu informasi yang diberikan harus mampu dimengerti oleh investor. Namun pada kenyataannya, insider trading menyebabkan pasar tidak lagi mempraktikan transparency information. Jaffe (1974) menemukan bahwa terdapat praktik insider yang mendapatkan informasi yang tidak mencerminkan harga pasar saat ini. Dengan informasi tersebut, para insider trading mendapatkan profit melalui trading yang dilakukan atas informasi tersebut (Seyhun, 1986).

Fenomena yang menyebabkan pasar menjadi tidak efisien salah satunya adalah weekend effect, yaitu terdapat pengaruh yang signifikan antara hari Senin atau Jumat terhadap daily return index yang menyebabkan adanya pola perdagangan pasar (Cross, 1973). Penjelasan Fields (1931, 1934) dan Chen dan Singal (2003) cukup sederhana, yakni penutupan pasar pada akhir pekan menyebabkan para investor berhenti untuk melakukan aktivitas short-long dan kembali melakukannya pada hari pertama pembukaan pasar yaitu hari Senin, sehingga menimbulkan pola transaksi yang menyebabkan adanya weekend effect yang return-nya dapat diprediksi oleh market. Hal yang menarik dari fenomena ini adalah weekend effect dapat menjadi indikator penilaian efisiensi suatu pasar saham seperti hipotesis yang dikemukakan oleh Eugene Fama.

Kaminsky dan Reinhart (1999) menyatakan krisis ekonomi Asia 1997-1998 ditandai oleh mata uang dan sektor perbankan secara twin crises. Pelemahan mata uang dan sektor keuangan menyebabkan penurunan ekonomi secara riil yaitu ekonomi Indonesia dan Thailand dengan pertumbuhan GDP negatif pada saat itu. Mata uang rupiah menyentuh angka tertinggi pada Juni 1998 senilai Rp16.650 atau 1 US Dollar yang mampu menurunkan level of demand pada sektor riil (Lee \& Makhija, 2009) serta penurunan output, lapangan pekerjaan dan hutang pemerintah yang signifikan (Reinhart \& Rogoff, 2009). Krisis dapat disebabkan oleh intervensi bank sentral yang berlebihan dalam menurunkan suku bunga (Austrian Business Cycle Theory) yang berdampak pada penguatan nilai aset secara tidak wajar yang terjadi pada tahun 2008. Krisis moneter global tersebut melanda sebagian besar negara dunia terutama yang berhubungan erat dengan Amerika Serikat dalam konteks ekonomi.

Krisis ekonomi berkaitan erat dengan pelemahan indeks saham, yakni dampak krisis pada sektor riil menyebabkan banyak perusahaan relatif underperform terhadap kondisi normal (Chen \& Miller, 2007), sementara di sisi lain krisis secara nasional menyebabkan kondisi ekonomi investor secara individu terganggu yang berdampak pada pasar saham secara simultan (Granger 
\& Morgenstern, 1970). Kondisi underperform dari sebagian besar perusahaan menimbulkan aktivitas spekulasi yang meningkat dalam konteks frekuensi akibat pasar yang tidak efisien menghasilkan potensi weekend effect. Namun, belum ada bukti bahwa dampak krisis terhadap pasar saham akan berlangsung dalam jangka panjang (Granger \& Morgenstern, 1970) karena adanya penyesuaian efisiensi pasar.

Weekend effect diduga terjadi pada saat pascakrisis karena kondisi pasar dan performa perusahaan menyebabkan pasar saham tidak efisien sehingga menimbulkan banyak aktivitas spekulatif dari para investor. Average daily return pada hari Senin pascakrisis tahun 1999-2003 yaitu $-0.26 \%,-0.29 \%,-0.37 \%,-0.26 \%$ dan $0.07 \%$ yang memiliki kecenderungan nilai negatif dibandingkan positif. Hal ini berlaku untuk pascakrisis 2009-2013 dengan nilai daily return pada hari Senin negatif untuk 4 tahun dan 1 tahun untuk nilai positif sedangkan pascakrisis 2012-2016 memberikan nilai daily return pada hari Senin negatif untuk 3 tahun dan 2 tahun positif.

Penelitian weekend effect banyak diteliti baik di Indonesia maupun di luar negeri karena fenomena ini dapat mencerminkan kondisi efficient market pasar saham suatu negara. Penelitian yang dilakukan oleh Gao dkk. (2015) menyatakan bahwa weekend effect terjadi pada sahamsaham yang diperbolehkan untuk short selling maupun tidak, sehingga weekend effect tidak terjadi pada saham tertentu melainkan hanya mencakup sebagian besar saham. Penelitian luar negeri lainnya dari Olson dkk. (2015) menyimpulkan bahwa weekend effect terjadi di masa lalu sebagai fenomena yang muncul akibat pasar yang tidak efisien, namun saat ini weekend effect telah hilang sebagai bentuk dari penyesuaian harga, akibat dari faktor-faktor pendorong terjadinya efficient market. Penelitian Indonesia dilakukan oleh Budileksmana (2005) menunjukkan bahwa terdapat return negatif pada hari Senin. Budileksmana juga menyatakan bahwa apabila daily return pada hari Senin dapat diprediksi maka investor mampu untuk memprediksi return sebagai pola investasi mingguan.

Budileksmana \& Hambayanti (2006) menyatakan bahwa weekend effect terjadi pada indeks dengan kapitalisasi kecil dan mulai menghilang apabila kapitalisasi itu semakin besar karena short selling sebagai penyebab terjadinya weekend effect sulit untuk dilakukan terhadap kapitalisasi index yang besar. Hasil penelitian terdahulu menyimpulkan bahwa weekend effect terjadi di masa lalu sebagai fenomena ketidakefisienan pasar saham yang diakibatkan oleh aktivitas para spekulan sehingga menghasilkan pola perdagangan tertentu.

Hipotesis Fama menyimpulkan bahwa untuk mencapai pasar yang efisien, harga saham harus mencerminkan segala informasi yang disalurkan ke publik melalui praktik transparansi informasi. Namun, strong efficiency market masih sulit untuk dicapai hingga saat ini karena terdapat fenomena-fenomena seperti weekend effect yang mempengaruhinya. Penelitian berawal dari konsep weekend effect terjadi saat pascakrisis yang dikarenakan krisis ekonomi memiliki efek penularan terhadap pasar saham. Wawasan terkait efisiensi pasar Indonesia akan berguna bagi analisa investor dalam memilih saham berdasarkan pola perdagangan yang terjadi pascakrisis melalui analisa weekend effect. Apakah weekend effect cenderung terjadi pascakrisis ekonomi yang berdampak pada ekonomi nasional?

\section{KERANGKA PEMIKIRAN DAN KAJIAN LITERATUR}

Pasar efisien yang dikemukakan oleh Fama (1991) menyimpulkan bahwa suatu pasar tidak dapat memberikan abnormal return atau pola perdagangan tanpa informasi yang beredar di publik. Weekend effect adalah suatu fenomena yang bertentangan dengan prinsip efficient market karena memberikan pola perdagangan pada hari tertentu tanpa informasi pasar yang disebabkan 
oleh aktivitas short oleh para investor. Short yang dilakukan oleh investor sebagian besar berasal dari investor pribadi, pemikirannya cukup sederhana, investor pribadi melakukan spekulasi long pada hari Jumat sebagai hasil evaluasi dari analisa mingguan kemudian kembali melakukan short pada hari Senin atau sebaliknya sebagai bagian dari reaksi terhadap pasar sehingga menyebabkan pola weekend effect.

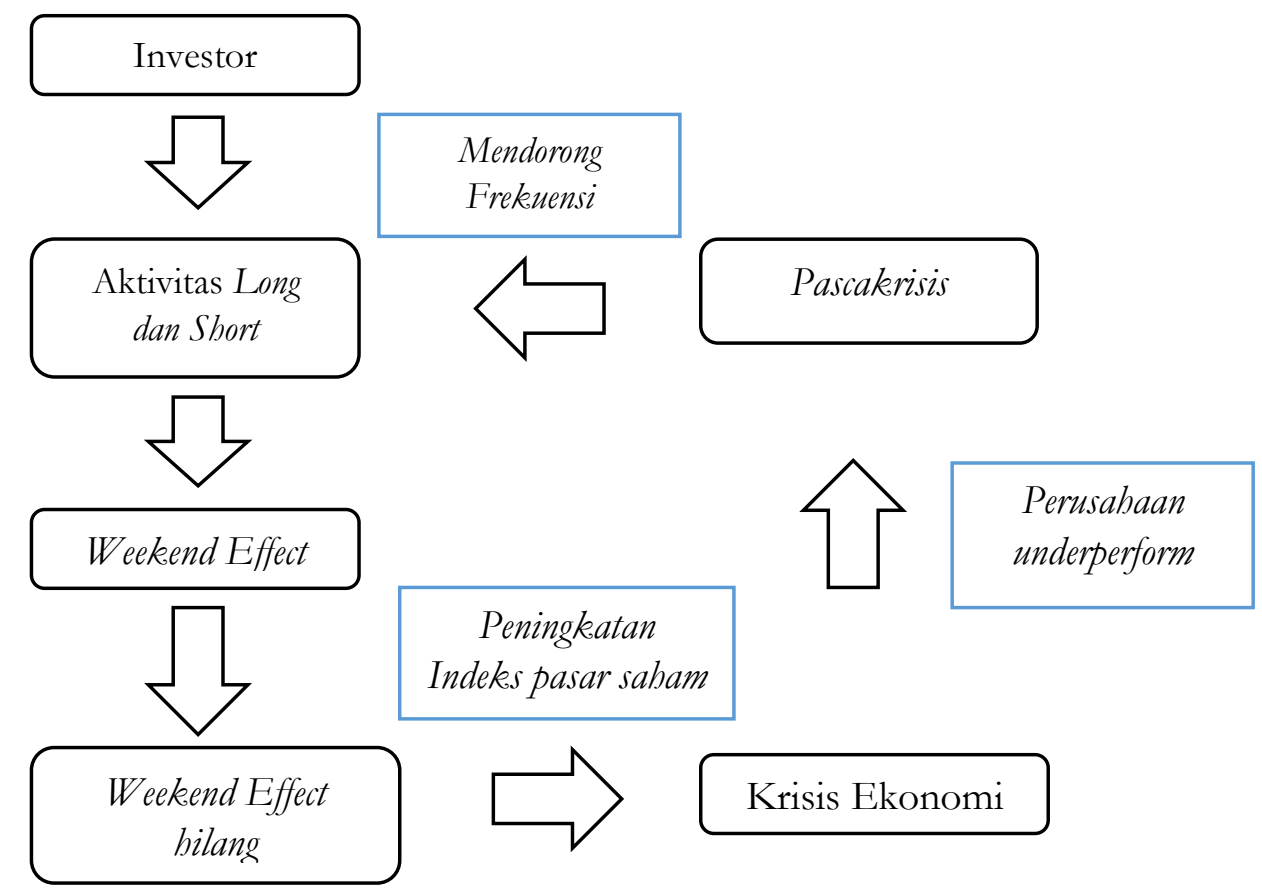

Gambar 1. Kerangka Konseptual Penelitian

Budileksmana \& Hambayanti (2006) mengatakan bahwa suatu indeks yang memiliki weekend effect adalah indeks yang memiliki kapitalisasi yang kecil sehingga mudah bagi investor untuk melakukan short yang mengakibatkan munculnya pola perdagangan pasar, sebaliknya aktivitas short sulit untuk dilakukan untuk indeks yang telah memiliki saham dengan kapitalisasi yang besar. Kerangka di atas menjelaskan bahwa terjadi peningkatkan volume transaksi sebagai bukti bahwa kapitalisasi pasar saham Indonesia semakin besar dan penambahan saham yang tergolong atas large capitalization. Skenario ini menunjukkan bahwa semakin besarnya kapitalisasi pasar suatu saham atau indeks yang didorong oleh peningkatan volume transaksi, maka fenomena weekend effect akan perlahan hilang seiring dengan bertambahnya volume transaksi dan saham large capitalization tanpa mengabaikan peran informasi pada efficient market.

Olson dkk. (2015) mengatakan bahwa weekend effect dapat disebabkan oleh pola transaksi yang terjadi akibat penyesuaian terhadap pasar saham pascakrisis. Pada saat pascakrisis, investor cenderung melakukan spekulasi terhadap saham-saham tertentu yang berpotensi memberikan return besar sebagai bentuk pemulihan dari krisis. Menurut Olson, aktivitas short \& long memiliki frekuensi yang lebih tinggi pada saat pascakrisis daripada kondisi normal yang dianggap lebih efisien.

Budileksamana (2005) melakukan penelitian dengan menggunakan data IHSG tahun 19992004 dan membuktikan bahwa return pada hari Senin lebih rendah dibandingkan dengan return pada hari lainnya. Weekend effect yang terjadi di Indonesia disebabkan oleh masalah likuiditas, investor pribadi yang mendominasi pasar menimbulkan adanya pola perdagangan pada hari tertentu yaitu hari Senin atau Jumat secara spesifik. Gao dkk. (2015) melakukan penelitian 
weekend effect menggunakan short-selling pada indeks saham dan menemukan bahwa weekend effect terjadi kepada saham yang memiliki kemungkinan besar untuk di-short atau dispekulasi oleh investor dan semakin berkembangnya option market akan menurunkan ketertarikan investor untuk melakukan short; dengan kata lain weekend effect akan menurun atau hilang seiring berkembangnya pasar derivatif.

Muzakir (2017) melakukan penelitian terhadap weekend effect dengan menggunakan data indeks LQ-45 pada periode 2016-2017. Penelitian ini menunjukkan bahwa tidak terdapat weekend effect pada data yang diteliti. Artinya return saham tidak dapat diprediksi, dalam hal ini return pada hari Senin tidak selalu lebih rendah dan return pada hari Jumat tidak selalu lebih tinggi dalam kurun waktu satu minggu. Ketika dilakukan pengujian, ditemukan bahwa return ratarata dari saham sama antara hari Senin, Jumat, dan hari lainnya. Tidak adanya dominasi signifikan ini membuktikan bahwa tidak terjadi anomali pada pasar saham Indonesia yang disebabkan oleh weekend effect.

Olson dkk. (2015) menyimpulkan bahwa weekend effect terjadi akibat penyesuaian terhadap suatu peristiwa seperti krisis keuangan sehingga dalam jangka pendek akan terjadi pola perdagangan pada daily return hari tertentu sebelum dilakukan penyesuaian terhadap anomali yang terjadi. Penelitian yang dilakukan oleh Olson menghasilkan negative weekend effect namun positif setelah terjadinya krisis keuangan global tahun 1973-1974. Hal tersebut menunjukkan bahwa weekend effect terjadi di masa lalu sebagai akibat dari fenomena keuangan seperti krisis keuangan. Budileksmana \& Hambayanti (2006) menemukan bahwa saham yang tergolong dalam LQ45 mengalami fenomena weekend effect secara signifikan karena intensitas saham LQ45 tergolong dalam small capitalization dan masih dikategorikan dalam bentuk pasar efisien lemah yang mendukung adanya weekend effect. Sedangkan weekend effect tidak terjadi pada indeks IHSG yang dipicu oleh saham large capitalization dengan intensitas rendah sehingga fenomena tersebut tidak terjadi.

\section{METODE PENELITIAN DAN DATA}

Penelitian weekend effect ini menggunakan metode regresi untuk mencari pengaruh antara hari dalam seminggu terhadap daily return IHSG secara signifikan. Daily return IHSG akan berperan sebagai dependent variable, sedangkan variabel hari senin hingga hari jumat berperan sebagai independent variable, yang dalam penelitian ini diwakili oleh dummy variable. Dengan menggunakan t-test, maka hasil regresi dapat digunakan untuk mencari hari tertentu yang memiliki pengaruh yang signifikan terhadap daily return IHSG. Variabel yang mempunyai pengaruh yang signifikan menunjukkan adanya pola perdagangan pasar saham pada hari tertentu.

Krisis memiliki efek penularan atau contagion effect yang berarti mampu memberikan dampak negatif terhadap sektor-sektor yang berhubungan. Krisis tahun 1998 dan 2008 menyebabkan penurunan yang signifikan terhadap IHSG pada saat itu. Pada pertengahan periode 1998, IHSG menyentuh titik terlemahnya dengan nilai 258 yaitu penurunan sebesar $64 \%$ dari titik tertingginya. Pada tahun 2008, IHSG menyentuh titik terlemahnya pada $1.111,4$ yaitu penurunan sebesar $60.32 \%$ dari titik tertingginya. Kedua data tersebut menyatakan bahwa krisis memiliki dampak yang signifikan terhadap pasar modal nasional.

Pada bagian latar belakang, peneliti memaparkan kecenderungan negatif pascakrisis yang menandakan potensi terjadinya weekend effect. Hipotesis menduga bahwa weekend effect cenderung terjadi saat pascakrisis sehingga periode pra-krisis akan menghasilkan pernyataan 


\section{4 | Bina Ekonomi}

negatif terhadap adanya weekend effect. Pra-krisis tahun 1997-1998 memiliki rata-rata daily return cenderung positif senilai $0.005 \%$ untuk 4 tahunan sedangkan untuk periode pra-krisis tahun 2008 senilai $-0.14 \%$. Data tersebut menunjukkan adanya perbedaan antara kedua periode krisis yang akan dianalisa pada bagian pembahasan empiris. Oleh karena itu, pada penelitian ini, kami mengambil dugaan sementara yaitu weekend effect terjadi pascakrisis yang disebabkan oleh efisiensi pasar yang menurun. Penurunan ini merupakan imbas dari krisis yang mempengaruhi sektor riil serta sebagian besar performa perusahaan. Kondisi perusahaan yang underperform meningkatkan frekuensi aktivitas spekulasi dari investor individu yang berpotensi memunculkan fenomena weekend effect.

Model regresi yang akan diestimasi adalah sebagai berikut:

$$
R I H S G_{I}=\alpha_{0}+\alpha_{1} R S E N_{t}+\alpha_{2} R S E L_{t}+\alpha_{3} R R A B_{t}+\alpha_{4} R K A M_{t}+\alpha_{5} R J U M_{t}+\varepsilon_{t}
$$

keterangan:

$$
\begin{aligned}
& R_{I H S G_{I}} \quad=\text { average daily return IHSG pada hari } \mathrm{t} \\
& \operatorname{RSEN}_{t} \quad=\text { dummy variable untuk hari Senin }(\text { Senin }=1 \text {; hari lainnya }=0) \\
& R S E L_{t} \quad=\text { dummy variable untuk hari Selasa (Selasa }=1 \text {; hari lainnya }=0 \text { ) } \\
& \left.R R A B_{t} \quad=\text { dummy variable untuk hari Rabu(Rabu = } 1 \text {; hari lainnya }=0\right) \\
& R K A M_{t} \quad=\text { dummy variable untuk hari Kamis (Kamis }=1 \text {; hari lainnya =0) } \\
& \text { RJUM }_{t} \quad=\text { dummy variable untuk hari Jumat (Jumat }=1 \text {; hari lainnya }=0 \text { ) } \\
& \alpha_{0}, \alpha_{1}, \alpha_{2}, \alpha_{3}, \alpha_{4}, \alpha_{5}=\text { koefisien regresi } \\
& \varepsilon_{t} \quad=\text { error term }
\end{aligned}
$$

Peneliti ingin melakukan uji untuk melihat apakah fenomena weekend effect terjadi di Indonesia. Penelitian ini menggunakan daily return IHSG sebagai dependent variable yang didukung oleh daily return harian sebagai independent variable. Dalam menurunkan model, peneliti berfokus pada pengaruh daily return pada hari Senin dan Jumat terhadap daily return IHSG.

Tujuan pengujian regresi ini adalah menemukan pengaruh antara return pada hari Senin dan Jumat terhadap R IHSG secara signifikan sehingga dapat menjawab hipotesis terjadinya fenomena weekend effect di Indonesia pada periode krisis. Pengujian ini akan menggunakan $t$-test sebagai cara untuk mengetahui pengaruh antara dependent dan independent variable secara signifikan, sehingga pada akhirnya dapat disimpulkan pengaruh antar variabel yang bertindak sebagai objek penelitian. Penelitian akan berfokus pada periode pra-krisis dan pascakrisis untuk mengetahui dampak krisis terhadap fenomena weekend effect. Apabila ditemukan bahwa daily return Senin atau Jumat memiliki t-test yang signifikan dengan R IHSG, maka kita dapat menyimpulkan bahwa terjadi weekend effect pada indeks IHSG Indonesia. Pengujian regresi ini dilakukan secara bertahap dari periode waktu tertentu sehingga dalam pengujiannya peneliti akan melakukan uji terhadap fenomena weekend effect yang terjadi pascakrisis seperti yang dikemukakan oleh Olson dkk. (2015). Terdapat 2 krisis keuangan global yang terjadi dalam range penelitian yaitu tahun 1998 dan 2008 sehingga akan dilakukan pengelompokkan periode waktu untuk menguji terjadinya weekend effect pascakrisis keuangan.

Penelitian ini menggunakan data sekunder, yang diambil dari Bloomberg berupa penutupan harga IHSG pada tahun 1992 hingga 2016 Populasi dalam penelitian ini adalah Indeks Harga Saham Gabungan (IHSG) di mana data yang digunakan adalah nilai indeks pada periode 19922016. Sampel yang diambil dalam penelitian ini disesuaikan dengan periode jendela kami. Dalam periode tersebut, peneliti akan melakukan penelitian khususnya pada krisis tahun 1998 dan 2008 secara berkala. Pada tahun 1998, indeks IHSG membutuhkan waktu 5 tahun untuk kembali pada 
titik semulanya yaitu pada nilai 720, sedangkan pada tahun 2008 indeks hanya membutuhkan waktu 3 tahun untuk pulih ke titik tertingginya yaitu 2800. Melalui data tersebut, peneliti akan menggunakan periode 4 tahun sebagai rata-rata kedua periode untuk menguji weekend effect saat pra-krisis dan pascakrisis. Krisis tahun 1997-1998 akan diuji terhadap kondisi pra-krisis 19931996 dan pascakrisis 1999-2002, sedangkan krisis tahun 2007-2008 akan diuji terhadap kondisi pra-krisis 2004-2007 dan pascakrisis pada 2008-2011. Data dari Bloomberg tersebut yang akan diolah menjadi daily return untuk keperluan kajian weekend effect.

\section{PEMBAHASAN DAN ANALISIS EMPIRIS}

Weekend effect terjadi karena terdapat return pada hari tertentu yang dapat diprediksi secara signifikan terhadap daily return IHSG. Krisis dapat menyebabkan penurunan secara tidak wajar pada indeks saham suatu negara akibat arus kas dalam negeri dan luar negeri yang tidak stabil sehingga harga saham-saham pada indeks tidak mencerminkan harga wajarnya dalam konteks penurunan. Pascakrisis adalah fase saat indeks mengalami pemulihan menuju harga wajarnya sehingga banyak menimbulkan spekulasi dari investor yang berusaha mencari saham yang berada di bawah harga wajarnya. Spekulasi tersebut dapat menyebabkan kenaikan/penurunan return yang signifikan, dengan kata lain mengabaikan hipotesis pasar efisien.

Krisis di Indonesia terjadi pada dua periode yaitu 1998 dan 2008. Pengujian asumsi klasik pada regresi menunjukkan adanya multikolinearitas antara variabel hari kamis dan jumat sehingga variabel RJUM yang merupakan salah satu objek penelitian tetap diuji dan variabel RKAM dihilangkan. Dugaan sementara menyatakan bahwa terjadi weekend effect pada pascakrisis di indeks Indonesia. Hasil regresi untuk periode pra-krisis 1997-1998 ditampilkan oleh Tabel 1.

Tabel 1. Hasil Regresi Pra-Krisis 1997-1998

\begin{tabular}{ccccc}
\hline Parameter & Koefisien & t Stat & P-value & Kesimpulan \\
\hline Intercept & 0,0015 & 2,2786 & 0,0229 & \\
Senin & $-0,0014$ & $-1,5586$ & 0,1194 & Tidak Signifikan \\
Selasa & $-0,0015$ & $-1,6304$ & 0,1034 & Tidak Signifikan \\
Rabu & 0,0001 & 0,0894 & 0,9287 & Tidak Signifikan \\
Jumat & 0,0000 & 0,0346 & 0,9724 & Tidak Signifikan \\
\hline
\end{tabular}

Tabel 1 menunjukkan hasil regresi terjadinya weekend effect pra-krisis 1998. Variabel Senin memiliki nilai $p$-value yang tidak signifikan pada level 5\% dengan koefisien negatif sebesar 0.0014. Variabel lainnya juga memiliki nilai $p$-value yang tidak signifikan terhadap daily return IHSG sehingga dapat disimpulkan bahwa weekend effect tidak terjadi pra-krisis tahun 1997-1998 saat frekuensi aktivitas spekulasi oleh investor individu masih rendah karena tidak terdapat perubahan fundamental perusahaan secara signifikan. Hal tersebut mendukung hipotesis peneliti bahwa weekend effect belum terjadi saat pra-krisis

Tabel 2. Hasil Regresi Pascakrisis 1997-1998

\begin{tabular}{lllll}
\hline Parameter & Koefisien & t Stat & P-value & Kesimpulan \\
\hline Intercept & 0,0023 & 1,8670 & 0,0622 & \\
Senin & $-0,0056$ & $-3,2221$ & 0,0013 & Signifikan
\end{tabular}


66 | Bina Ekonomi

\begin{tabular}{lllll} 
Selasa & $-0,0014$ & $-0,8097$ & 0,4183 & Tidak Signifikan \\
Rabu & $-0,0029$ & $-1,6910$ & 0,0911 & Tidak Signifikan \\
Jumat & $-0,0005$ & $-0,2818$ & 0,7781 & Tidak Signifikan \\
\hline
\end{tabular}

Tabel 2 menunjukkan hasil regresi terjadinya weekend effect pascakrisis 1997-1998. Variabel Senin memiliki nilai $p$-value yang signifikan pada level $5 \%$ dengan koefisien negatif sebesar -0.0056. Variabel lainnya memiliki nilai $p$-value yang tidak signifikan terhadap daily return IHSG sehingga dapat disimpulkan bahwa weekend effect terjadi pascakrisis tahun 1998. Krisis tahun 1997-1998 disebabkan oleh hutang luar negeri Indonesia yang menumpuk disertai pelemahan mata uang yang cukup dalam sehingga krisis tidak dapat dihindari, baik pada sektor perbankan maupun sektor riil. Proses pemulihan menyebabkan terjadinya weekend effect karena banyak investor yang melakukan spekulasi tanpa informasi yang beredar di publik seperti yang telah dijelaskan di atas. Penelitian pascakrisis 1997-1998 mendukung hipotesis peneliti yaitu weekend effect cenderung terjadi pada pascakrisis dengan pola perdagangan Senin bernilai negatif.

Tabel 3. Hasil Regresi Pra-Krisis 2007-2008

\begin{tabular}{lllll}
\hline Parameter & Koefisien & $\boldsymbol{t}$ Stat & $\boldsymbol{P}$-value & Kesimpulan \\
\hline Intercept & 0,00079 & 0,88113 & 0,37847 & \\
Senin & $-0,00225$ & $-1,75719$ & 0,07920 & Tidak Signifikan \\
Selasa & 0,00120 & 0,95009 & 0,34230 & Tidak Signifikan \\
Rabu & 0,00216 & 1,70963 & 0,08766 & Tidak Signifikan \\
Jumat & 0,00275 & 2,14732 & 0,03202 & Tidak Signifikan \\
\hline
\end{tabular}

Tabel 3 menunjukkan hasil regresi terjadinya weekend effect saat pra-krisis 2007-2008. Variabel Senin memiliki nilai $p$-value yang tidak signifikan pada level 5\% dengan koefisien negatif sebesar -0.00225 terhadap daily return IHSG. Variabel lainnya juga memiliki nilai $p$-value yang tidak signifikan, sehingga dapat disimpulkan bahwa weekend effect tidak terjadi saat pra-krisis 2007-2008. Hasil penelitian ini mendukung hipotesis peneliti bahwa weekend effect tidak terjadi saat pra-krisis melainkan cenderung terjadi saat pascakrisis.

Tabel 4. Hasil Regresi Pascakrisis 2007-2008

\begin{tabular}{lllll}
\hline Parameter & Koefisien & t Stat & P-value & Kesimpulan \\
\hline Intercept & 0,000427 & 0,454725 & 0,649408 & \\
Senin & $-0,000863$ & $-0,649312$ & 0,516290 & Tidak Signifikan \\
Selasa & 0,000954 & 0,721042 & 0,471057 & Tidak Signifikan \\
Rabu & 0,003008 & 2,278427 & 0,022917 & Tidak Signifikan \\
Jumat & 0,001073 & 0,802688 & 0,422351 & Tidak Signifikan \\
\hline
\end{tabular}

Tabel 4 menunjukkan hasil regresi terjadinya weekend effect saat pascakrisis tahun 20072008. Variabel Senin dan Jumat memiliki nilai $p$-value yang tidak signifikan terhadap daily return IHSG sehingga dapat disimpulkan bahwa tidak terjadi weekend effect pascakrisis tahun 2008 . 
Variabel lainnya juga memiliki $p$-value yang tidak signifikan terhadap dependent variable. Krisis tahun 2007-2008 terjadi akibat suprime mortgage dari Amerika Serikat yang menyebabkan krisis keuangan global, di mana banyaknya arus kas yang keluar menyebabkan krisis perbankan terutama pasar saham di Indonesia. Penelitian ini menolak hipotesis peneliti bahwa weekend effect cenderung terjadi pascakrisis sehingga tidak ada pola perdagangan harian pada IHSG pascakrisis keuangan global.

Penelitian weekend effect yang terjadi saat pascakrisis memberikan pro dan kontra terhadap hipotesis peneliti. Pascakrisis 1998 memberikan hasil positif terhadap penelitian weekend effect, sedangkan periode krisis 2008 memberikan hasil negatif terkait uji weekend effect. Peneliti melakukan analisa terhadap krisis yang memiliki dampak yang signifikan terhadap Indonesia yaitu pada tahun 1998 dan 2008. Hasilnya, peneliti mendapatkan bahwa krisis yang terjadi pada tahun 1998 berbeda dengan krisis pada tahun 2008 dari segi dampaknya. Pada tahun 1998, Indonesia terkena imbas secara keseluruhan yaitu sektor riil dan sektor keuangan sedangkan pada tahun 2008, krisis moneter global hanya berimbas pada sektor keuangan.

Krisis 2007-2008 melanggar asumsi utama penelitian yaitu weekend effect terjadi pascakrisis saat kondisi perusahaan berada pada underperform sebagai sebab dari pelemahan indeks yang dikemukakan oleh Chen dan Miller (2007). Krisis keuangan global tidak melibatkan sektor riil melainkan capital outflow yang meningkat, keluarnya dana asing menurukan kinerja indeks IHSG dari nilai wajarnya yang berdampak pada pasar saham secara simultan seperti yang dikemukakan oleh Granger (2007). Oleh sebab itu, indeks IHSG saat krisis tahun 2007-2008 hanya membutuhkan waktu 3 tahun pemulihan untuk mencapai titik sebelum krisisnya dibandingkan dengan tahun 1998 yang membutuhkan 5 tahun pemulihan indeks. Pertumbuhan PDB Indonesia tahun 2008 sebesar $4.6 \%$ menjadi bukti yang kuat bahwa sebagian besar perusahaan tidak terdampak krisis keuangan global secara riil sehingga faktor utama terjadinya weekend effect yaitu meningkatnya aktivitas spekulasi oleh investor ditengah ketidakpastian ekonomi terutama terhadap sektor riil nasional. Kesimpulannya, weekend effect hanya terjadi pada periode krisis yang memiliki dampak terhadap sektor riil sehingga menyebabkan perusahaan berada di kondisi underperform.

\section{SIMPULAN}

Berdasarkan hasil pengujian, peneliti menyimpulkan beberapa hal. Pertama, Weekend Effect terjadi pada periode krisis tahun 1997-1998, dimulai dari kondisi tidak adanya weekend effect saat pra-krisis tahun 1993-1996 dan adanya fenomena weekend effect pada pascakrisis 1999-2002 dengan pola perdagangan harian negatif. Kedua, Weekend Effect tidak terjadi pada periode krisis tahun 2007-2008, dimulai dari kondisi tidak adanya weekend effect saat pra-krisis tahun 2003-2006 dan pascakrisis tahun 2009-2012. Ketiga, Weekend effect terjadi saat pascakrisis yang memiliki dampak terhadap sektor riil yang menyebabkan adanya pola transaksi pada pasar modal. Pascakrisis yang tidak berdampak pada performa perusahaan tidak menunjukkan adanya fenomena weekend effect. Keempat, krisis ekonomi yang berdampak pada sektor riil memiliki periode pemulihan yang cenderung lama yaitu 5 tahun pada krisis 1997-1998 dibandingkan krisis 2007-2008 dengan periode 3 tahun. Proses pemulihan indeks yang lama memperpanjang periode investor dalam melakukan spekulasi. Kelima, krisis pada sektor riil menyebabkan kinerja perusahaan berada pada kondisi underperform sehingga meningkatkan frekuensi aktivitas spekulasi oleh investor sebagai faktor utama terjadinya weekend effect. 


\section{DAFTAR PUSTAKA}

Budileksmana, A. (2005). Fenomena The Monday Effect di Bursa Efek Jakarta. Solo: SNA VIII.

Biais, B. (1993). Price Formation and Equilibrium Liquidity in Fragmented and Centralized Markets. The Journal of Finance, 48(1), 157-185.

Chen, H., \& Singal, V. (2003). Role of Speculative Short Sales in Price Formation: The Case of the Weekend Effect. The Journal of Finance, 58(2), 685-705.

Cross, F. (1973). The Behavior of Stock Prices on Fridays and Mondays. Financial Analysts Journal, 29(6), 67-69.

Easley, D., \& O'Hara, M. (1995). Market Microstructure. Handbooks in Operations Research and Management Science, 9, 357-383.

Fama, E. F. (1991). Efficient Capital Markets: II. The Journal of Finance, 46(5), 1575-1617.

Fields, M. J. (1931). Stock Prices: A Problem in Verification. The Journal of Business of the University of Chicago, 4(4), 415-418.

Fields, M. J. (1934). Security Prices and Stock Exchange Holidays in Relation to Short Selling. The Journal of Business of the University of Chicago, 7(4), 328-338.

Gao, P. dkk. (2015). Short Sales and The Weekend Effect-Evidence from a Natural Experiment. Journal of Financial Markets, 26, 85-102.

Granger, C. W. J., \& Morgenstern, O. (1970). Predictability of Stock Market Prices. Heath Lexington Books.

Hambayanti, S., \& Budileksmana, A. (2006). Stabilitas Fenomena the Monday Effect di Bursa Efek Jakarta. Journal of Accounting and Investment, 7(2), 195-218.

Jaffe, J. F. (1974). Special Information and Insider Trading. The Journal of Business, 47(3), 410-428.

Kaminsky, G. L., \& Reinhart, C. M. (1999). The Twin Crises: The Causes of Banking and Balance-ofPayments Problems. American Economic Review, 89(3), 473-500.

Lee, S. H., \& Makhija, M. (2009). Flexibility in Internationalization: Is It Valuable During an Economic Crisis? Strategic Management Journal, 30(5), 537-555.

Muzakir, M. F. A. (2017). Analisis Gejala Akhir Pekan (the Weekend Effect) terhadap Return Saham LQ45 di Bursa Efek Indonesia Periode 2016. Jurnal Riset Akuntansi Mercu Buana, 3(2), 121-130.

Olson, D., Mossman, C., \& Chou, N. T. (2015). The Evolution of the Weekend Effect in US Markets. The Quarterly Review of Economics and Finance, 58, 56-63.

Reinhart, C. M., \& Rogoff, K. S. (2009). The Aftermath of Financial Crises. American Economic Review, 99(2), 466-72.

Seyhun, H. N. (1986). Insiders' Profits, Costs of Trading, and Market Efficiency. Journal of Financial Economics, 16(2), 189-212. 


\section{LAMPIRAN}

\section{A. Uji Asumsi Klasik Pra-Krisis 1997-1998}

1. Uji Normalitas

$\begin{array}{ll}\text { Series: Residuals } \\ \text { Sample } 1967 \\ \text { Obsenuations } 967 \\ \text { Mean } & 8.38 \mathrm{e}-19 \\ \text { Median } & -0.000253 \\ \text { Maximum } & 0.056596 \\ \text { Minimum } & -0.041524 \\ \text { Std. Dev. } & 0.008970 \\ \text { Skewness } & 0.249864 \\ \text { Kurtosis } & 7.313468 \\ & \\ \text { Jarque-Bera } & 759.7289 \\ \text { Probability } & 0.000000\end{array}$

2. Uji Multikolinearitas

\begin{tabular}{|crrrr|}
\hline & SENIN & SELASA & \multicolumn{1}{c|}{ RABU } & \multicolumn{1}{c|}{ JUMAT } \\
\hline \hline SENIN & 1.000000 & -0.253383 & -0.250161 & -0.248547 \\
SELASA & -0.253383 & 1.000000 & -0.254203 & -0.252563 \\
RABU & -0.250161 & -0.254203 & 1.000000 & -0.249351 \\
JUMAT & -0.248547 & -0.252563 & -0.249351 & 1.000000 \\
\hline
\end{tabular}

3. Uji Heteroskedastisitas 


\begin{tabular}{|c|c|c|c|c|}
\hline \multicolumn{5}{|c|}{$\begin{array}{l}\text { Heteroskedasticity Test: White } \\
\text { Null hypothesis: Homoskedasticity }\end{array}$} \\
\hline F-statistic & 0.696764 & \multicolumn{2}{|c|}{ Prob. $F(4,962)$} & 0.5943 \\
\hline Obs*R-squared & 2.793449 & \multicolumn{2}{|c|}{ Prob. Chi-Square(4) } & 0.5930 \\
\hline Scaled explained SS & 8.727221 & \multicolumn{2}{|c|}{ Prob. Chi-Square(4) } & 0.0683 \\
\hline \multirow{6}{*}{\multicolumn{5}{|c|}{$\begin{array}{l}\text { Test Equation: } \\
\text { Dependent Variable: RESID } 2 \\
\text { Method: Least Squares } \\
\text { Date: 02/11/20 Time: } 14: 01 \\
\text { Sample: } 1967 \\
\text { Included observations: } 967\end{array}$}} \\
\hline & & & & \\
\hline & & & & \\
\hline & & & & \\
\hline & & & & \\
\hline & & & & \\
\hline Variable & Coefficient & Std. Error & t-Statistic & Prob. \\
\hline C & $7.94 \mathrm{E}-05$ & $1.47 E-05$ & 5.415003 & 0.0000 \\
\hline SENIN² & $-1.13 E-05$ & $2.07 E-05$ & -0.547192 & 0.5844 \\
\hline SELASAn2 & $-1.01 E-05$ & $2.05 E-05$ & -0.492194 & 0.6227 \\
\hline 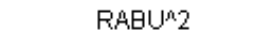 & $1.58 \mathrm{E}-05$ & $2.06 \mathrm{E}-05$ & 0.763998 & 0.4451 \\
\hline JUMAT ${ }^{n} 2$ & $1.06 \mathrm{E}-05$ & $2.07 E-05$ & 0.513584 & 0.6077 \\
\hline R-squared & 0.002889 & \multicolumn{2}{|c|}{ Mean dependent var } & $8.04 E-05$ \\
\hline Adjusted R-squared & -0.001257 & \multicolumn{2}{|c|}{ S.D. dependent var } & 0.000202 \\
\hline S.E. of regression & 0.000202 & \multicolumn{2}{|c|}{ Akaike info criterion } & -14.16932 \\
\hline Sum squared resid & $3.93 \mathrm{E}-05$ & \multicolumn{2}{|c|}{ Schwarz criterion } & -14.14412 \\
\hline Log likelihood & 6855.866 & \multicolumn{2}{|c|}{ Hannan-Quinn criter. } & -14.15973 \\
\hline F-statistic & 0.696764 & \multicolumn{2}{|c|}{ Durbin-Watson stat } & 1.656602 \\
\hline Prob(F-statistic) & 0.594266 & & & \\
\hline
\end{tabular}

4. Uji Autokorelasi

Breusch-Godfrey Serial Correlation LM Test:

Null hypothesis: No serial correlation at up to 2 lags

\begin{tabular}{|c|c|c|c|c|}
\hline $\begin{array}{l}\text { F-statistic } \\
\text { Obs*R-squared }\end{array}$ & $\begin{array}{l}69.42365 \\
122.1874\end{array}$ & \multicolumn{2}{|c|}{$\begin{array}{l}\text { Prob. } \mathrm{F}(2,960) \\
\text { Prob. Chi-Square(2) }\end{array}$} & $\begin{array}{l}0.0000 \\
0.0000\end{array}$ \\
\hline \multicolumn{5}{|c|}{$\begin{array}{l}\text { Test Equation: } \\
\text { Dependent Variable: RESID } \\
\text { Method: Least Squares } \\
\text { Date: } 02 / 11 / 20 \text { Time: } 14: 03 \\
\text { Sample: } 1967 \\
\text { Included observations: } 967 \\
\text { Presample missing value lagged residuals set to zero. }\end{array}$} \\
\hline Variable & Coefficient & Std. Error & t-Statistic & Prob. \\
\hline $\begin{array}{l}\text { C } \\
\text { SENIN } \\
\text { SELASA } \\
\text { RABU } \\
\text { JUMAT } \\
\text { RESID(-1) } \\
\text { RESID(-2) }\end{array}$ & $\begin{array}{r}-3.29 \mathrm{E}-05 \\
7.03 \mathrm{E}-05 \\
-7.18 \mathrm{E}-05 \\
0.000155 \\
2.36 \mathrm{E}-05 \\
0.363662 \\
-0.024665\end{array}$ & $\begin{array}{l}0.000610 \\
0.000860 \\
0.000854 \\
0.000859 \\
0.000861 \\
0.032281 \\
0.032289\end{array}$ & $\begin{array}{r}-0.053835 \\
0.081769 \\
-0.084042 \\
0.180449 \\
0.027478 \\
11.26561 \\
-0.763867\end{array}$ & $\begin{array}{l}0.9571 \\
0.9348 \\
0.9330 \\
0.8568 \\
0.9781 \\
0.0000 \\
0.4451\end{array}$ \\
\hline $\begin{array}{l}\text { R-squared } \\
\text { Adjusted R-squared } \\
\text { S.E. of regression } \\
\text { Sum squared resid } \\
\text { Log likelihood } \\
\text { F-statistic } \\
\text { Prob(F-statistic) }\end{array}$ & $\begin{array}{l}0.126357 \\
0.120897 \\
0.008411 \\
0.067911 \\
3251.959 \\
23.14122 \\
0.000000\end{array}$ & $\begin{array}{l}\text { Mean depen } \\
\text { S.D. depend } \\
\text { Akaike info c } \\
\text { Schwarz crit } \\
\text { Hannan-Qui } \\
\text { Durbin-Wats }\end{array}$ & $\begin{array}{l}\text { ent var } \\
\text { nt var } \\
\text { terion } \\
\text { ion } \\
\text { a criter. } \\
\text { n stat }\end{array}$ & $\begin{array}{r}8.38 \mathrm{E}-19 \\
0.008970 \\
-6.711394 \\
-6.676111 \\
-6.697962 \\
2.000868\end{array}$ \\
\hline
\end{tabular}


5. Output Model

\begin{tabular}{|c|c|c|c|c|}
\hline \multicolumn{5}{|c|}{$\begin{array}{l}\text { Dependent Variable: RETURN } \\
\text { Method: Least Squares } \\
\text { Date: } 02 / 11 / 20 \text { Time: } 13: 59 \\
\text { Sample: } 1967 \\
\text { Included observations: } 967\end{array}$} \\
\hline Variable & Coefficient & Std. Error & t-Statistic & Prob. \\
\hline $\mathrm{c}$ & 0.001486 & 0.000652 & 2.278607 & 0.0229 \\
\hline SENIN & -0.001432 & 0.000919 & -1.558590 & 0.1194 \\
\hline SELASA & -0.001488 & 0.000913 & -1.630351 & 0.1034 \\
\hline RABU & $8.21 \mathrm{E}-05$ & 0.000917 & 0.089449 & 0.9287 \\
\hline JUMAT & $3.18 \mathrm{E}-05$ & 0.000920 & 0.034592 & 0.9724 \\
\hline R-squared & 0.006697 & \multicolumn{2}{|c|}{ Mean dependent var } & 0.000918 \\
\hline Adjusted R-squared & 0.002567 & \multicolumn{2}{|c|}{ S.D. dependent var } & 0.009001 \\
\hline S.E. of regression & 0.008989 & \multicolumn{2}{|c|}{ Akaike info criterion } & -6.580447 \\
\hline Sum squared resid & 0.077734 & \multicolumn{2}{|c|}{ Schwarz criterion } & -6.555244 \\
\hline Log likelihood & 3186.646 & \multirow{2}{*}{\multicolumn{2}{|c|}{$\begin{array}{l}\text { Hannan-Quinn criter. } \\
\text { Durbin-Watson stat }\end{array}$}} & -6.570853 \\
\hline F-statistic & 1.621488 & & & 1.290440 \\
\hline $\operatorname{Prob}(\mathrm{F}-\mathrm{statistic})$ & 0.166633 & & & \\
\hline
\end{tabular}

\section{B. Uji Asumsi Klasik Pascakrisis 1997-1998}

1. Uji Normalitas

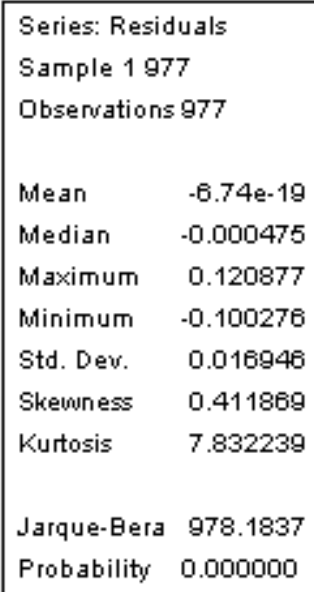

2. Uji Multikolinearitas

\begin{tabular}{|crrrr|}
\hline & SENIN & \multicolumn{1}{c}{ SELASA } & \multicolumn{1}{c|}{ RABU } & \multicolumn{1}{c|}{ JUMAT } \\
\hline \hline SENIN & 1.000000 & -0.250122 & -0.251700 & -0.244586 \\
SELASA & -0.250122 & 1.000000 & -0.257397 & -0.250122 \\
RABU & -0.251700 & -0.257397 & 1.000000 & -0.251700 \\
JUMAT & -0.244586 & -0.250122 & -0.251700 & 1.000000 \\
\hline
\end{tabular}

3. Uji Heteroskedastisitas 
Heteroskedasticity Test: White

Null hypothesis: Homoskedasticity

\begin{tabular}{llll}
\hline \hline F-statistic & 0.604434 & Prob. F(4,972) & 0.6595 \\
Obs*R-squared & 2.424145 & Prob. Chi-Square(4) & 0.6583 \\
Scaled explained SS & 8.196623 & Prob. Chi-Square(4) & 0.0846 \\
\hline
\end{tabular}

Test Equation:

Dependent Variable: RESID ${ }^{n} 2$

Method: Least Squares

Date: 02/11/20 Time: $14: 18$

Sample: 1977

Included observations: 977

\begin{tabular}{|crllr}
\hline \hline \multicolumn{1}{c}{ Variable } & Coefficient & Std. Error & t-Statistic & Prob. \\
\hline \hline C & 0.000270 & $5.40 \mathrm{E}-05$ & 4.990934 & 0.0000 \\
SENIN $^{n} 2$ & $8.14 \mathrm{E}-05$ & $7.65 \mathrm{E}-05$ & 1.063073 & 0.2880 \\
SELASAn2 $^{2}$ & $3.72 \mathrm{E}-05$ & $7.59 \mathrm{E}-05$ & 0.489742 & 0.6244 \\
RABU 2 & $-1.29 \mathrm{E}-05$ & $7.57 \mathrm{E}-05$ & -0.170388 & 0.8647 \\
JUMAT 2 & $-1.92 \mathrm{E}-05$ & $7.65 \mathrm{E}-05$ & -0.250821 & 0.8020 \\
\hline \hline R-squared & 0.002481 & Mean dependent var & 0.000287 \\
Adjusted R-squared & -0.001624 & S.D. dependent var & 0.000750 \\
S.E. of regression & 0.000751 & Akaike info criterion & -11.54562 \\
Sum squared resid & 0.000548 & Schwarz criterion & -11.52062 \\
Log likelihood & 5645.036 & Hannan-Quinn criter. & -11.53611 \\
F-statistic & 0.604434 & Durbin-Watson stat & 1.652261 \\
Prob(F-statistic) & 0.659518 & & & \\
\hline \hline
\end{tabular}

4. Uji Autokorelasi 
Breusch-Godfrey Serial Correlation LM Test:

Null hypothesis: No serial correlation at up to 2 lags

\begin{tabular}{llll}
\hline \hline F-statistic & 9.498950 & Prob. F(2,970) & 0.0001 \\
Obs*R-squared & 18.76743 & Prob. Chi-Square(2) & 0.0001 \\
\hline \hline
\end{tabular}

Test Equation:

Dependent Variable: RESID

Method: Least Squares

Date: 02/11/20 Time: $14: 21$

Sample: 1977

Included observations: 977

Presample missing value lagged residuals set to zero.

\begin{tabular}{crrrr}
\hline \hline Variable & Coefficient & Std. Error & t-Statistic & Prob. \\
\hline \hline C & $3.59 E-05$ & 0.001212 & 0.029659 & 0.9763 \\
SENIN & $8.08 \mathrm{E}-05$ & 0.001716 & 0.047057 & 0.9625 \\
SELASA & -0.000106 & 0.001702 & -0.062579 & 0.9501 \\
RABU & $-6.39 \mathrm{E}-05$ & 0.001697 & -0.037654 & 0.9700 \\
JUMAT & $-8.89 \mathrm{E}-05$ & 0.001716 & -0.051790 & 0.9587 \\
RESID(-1) & 0.139480 & 0.032123 & 4.342016 & 0.0000 \\
RESID(-2) & -0.007295 & 0.032128 & -0.227066 & 0.8204 \\
\hline \hline R-squared & 0.019209 & Mean dependent var & $-6.74 \mathrm{E}-19$ \\
Adjusted R-squared & 0.013142 & S.D. dependent var & 0.016946 \\
S.E. of regression & 0.016834 & Akaike info criterion & -5.323640 \\
Sum squared resid & 0.274897 & Schwar criterion & -5.288644 \\
Log likelihood & 2607.598 & Hannan-Quinn criter. & -5.310324 \\
F-statistic & 3.166317 & Durbin-Watson stat & 1.998832 \\
Prob(F-statistic) & 0.004419 & & & \\
\hline \hline
\end{tabular}

\section{Output Model}

\begin{tabular}{|c|c|c|c|c|}
\hline \multicolumn{5}{|c|}{$\begin{array}{l}\text { Dependent Variable: RETURN } \\
\text { Method: Least Squares } \\
\text { Date: 02/11/20 Time: } 14: 21 \\
\text { Sample: } 1977 \\
\text { Included observations: } 977\end{array}$} \\
\hline Variable & Coefficient & Std. Error & t-Statistic & Prob. \\
\hline $\mathrm{C}$ & 0.002282 & 0.001222 & 1.867004 & 0.0622 \\
\hline SENIN & -0.005577 & 0.001731 & -3.222113 & 0.0013 \\
\hline SELASA & -0.001389 & 0.001716 & -0.809698 & 0.4183 \\
\hline RABU & -0.002894 & 0.001711 & -1.691043 & 0.0911 \\
\hline JUMAT & -0.000488 & 0.001731 & -0.281816 & 0.7781 \\
\hline R-squared & 0.013716 & \multicolumn{2}{|c|}{ Mean dependent var } & 0.000212 \\
\hline Adjusted R-squared & 0.009657 & \multicolumn{2}{|c|}{ S.D. dependent var } & 0.017064 \\
\hline S.E. of regression & 0.016981 & \multicolumn{2}{|c|}{ Akaike info criterion } & -5.308338 \\
\hline Sum squared resid & 0.280281 & \multicolumn{2}{|c|}{ Schwarz criterion } & -5.283341 \\
\hline Log likelihood & 2598.123 & \multicolumn{2}{|c|}{ Hannan-Quinn criter. } & -5.298827 \\
\hline F-statistic & 3.379397 & \multicolumn{2}{|c|}{ Durbin-Watson stat } & 1.723088 \\
\hline Prob(F-statistic) & 0.009322 & & & \\
\hline
\end{tabular}

\section{Uji Asumsi Klasik Pra-Krisis 2007-2008}


1. Uji Normalitas

\begin{tabular}{|ll||}
\hline Series: Residuals \\
Sample 1968 \\
Obsenuations 968 \\
Mean & $-6.08 \mathrm{e}-19$ \\
Median & $-2.00 \mathrm{e}-05$ \\
Maximum & 0.051122 \\
Minimum & -0.073581 \\
Std. Dev. & 0.012500 \\
Skewness & -0.444254 \\
Kurtosis & 6.120599 \\
& \\
Jarque-Bera & 424.6126 \\
Probability & 0.000000 \\
\hline \hline
\end{tabular}

2. Uji Multikolinearitas

\begin{tabular}{|crrrr|}
\hline & SENIN & \multicolumn{1}{c}{ SELASA } & \multicolumn{1}{c}{ RABU } & \multicolumn{1}{c|}{ JUMAT } \\
\hline \hline SENIN & 1.000000 & -0.249744 & -0.249744 & -0.240230 \\
SELASA & -0.249744 & 1.000000 & -0.258778 & -0.248919 \\
RABU & -0.249744 & -0.258778 & 1.000000 & -0.248919 \\
JUMAT & -0.240230 & -0.248919 & -0.248919 & 1.000000 \\
\hline
\end{tabular}

3. Uji Heteroskedastisitas

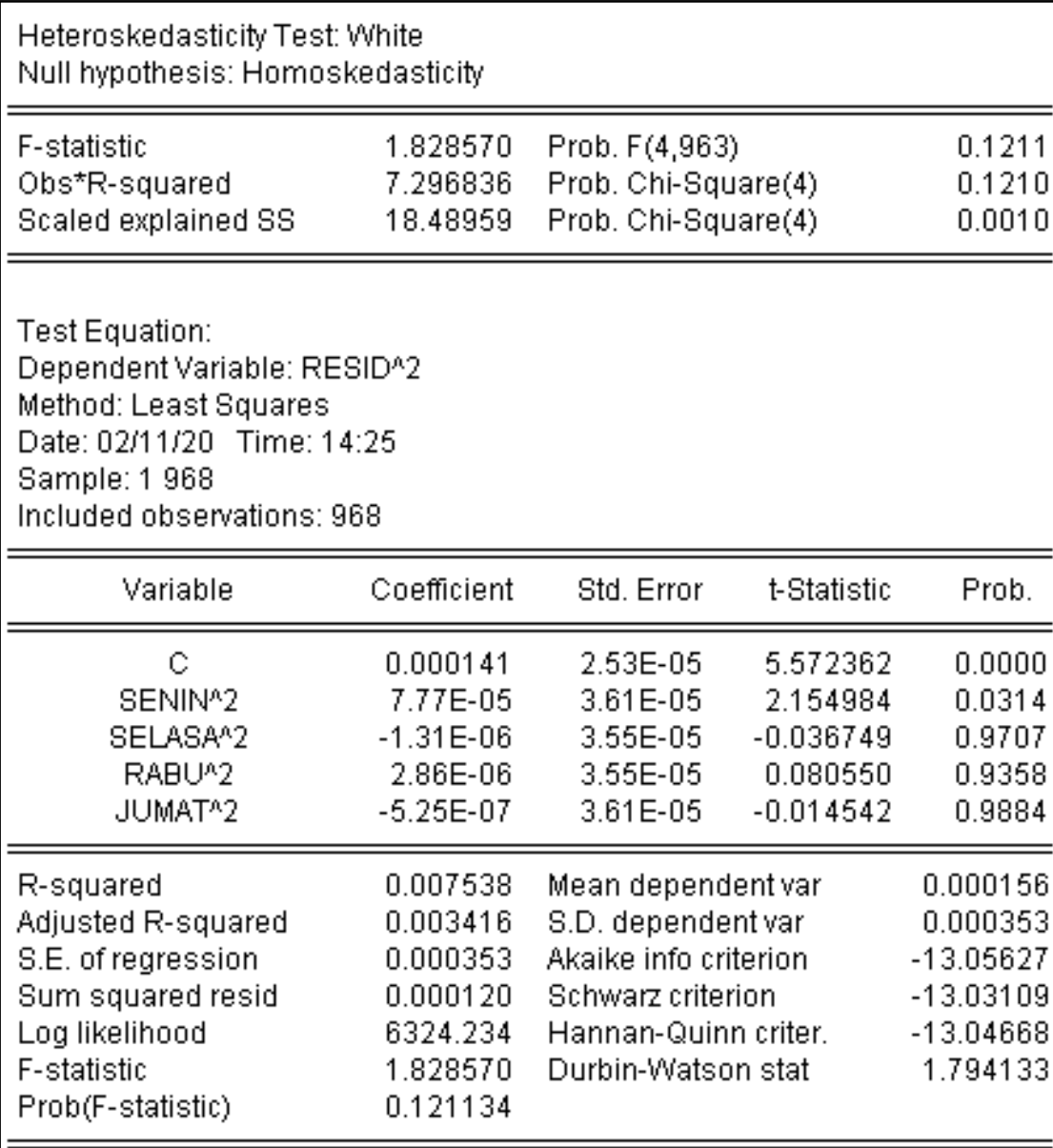

4. Uji Autokorelasi 


\begin{tabular}{|c|c|c|c|c|}
\hline $\begin{array}{l}\text { F-statistic } \\
\text { Obs*R-squared }\end{array}$ & $\begin{array}{l}13.35525 \\
26.17747\end{array}$ & \multicolumn{2}{|c|}{$\begin{array}{l}\text { Prob. } \mathrm{F}(2,961) \\
\text { Prob. Chi-Square(2) }\end{array}$} & $\begin{array}{l}0.0000 \\
0.0000\end{array}$ \\
\hline \multicolumn{5}{|c|}{$\begin{array}{l}\text { Test Equation: } \\
\text { Dependent Variable: RESID } \\
\text { Method: Least Squares } \\
\text { Date: } 02 / 11 / 20 \text { Time: } 14: 25 \\
\text { Sample: } 1968 \\
\text { Included observations: } 968 \\
\text { Presample missing value lagged residuals set to zero. }\end{array}$} \\
\hline Variable & Coefficient & Std. Error & t-Statistic & Prob. \\
\hline $\begin{array}{l}\text { C } \\
\text { SENIN } \\
\text { SELASA } \\
\text { RABU } \\
\text { JUMAT } \\
\text { RESID(-1) } \\
\text { RESID(-2) }\end{array}$ & $\begin{array}{r}1.06 \mathrm{E}-05 \\
0.000138 \\
-5.84 \mathrm{E}-05 \\
-2.34 \mathrm{E}-05 \\
-0.000109 \\
0.153641 \\
-0.084634\end{array}$ & $\begin{array}{l}0.000886 \\
0.001265 \\
0.001246 \\
0.001246 \\
0.001266 \\
0.032156 \\
0.032180\end{array}$ & $\begin{array}{r}0.011947 \\
0.108852 \\
-0.046884 \\
-0.018785 \\
-0.086464 \\
4.778027 \\
-2.630060\end{array}$ & $\begin{array}{l}0.9905 \\
0.9133 \\
0.9626 \\
0.9850 \\
0.9311 \\
0.0000 \\
0.0087\end{array}$ \\
\hline $\begin{array}{l}\text { R-squared } \\
\text { Adjusted R-squared } \\
\text { S.E. of regression } \\
\text { Sum squared resid } \\
\text { Log likelihood } \\
\text { F-statistic } \\
\text { Prob(F-statistic) }\end{array}$ & $\begin{array}{l}0.027043 \\
0.020968 \\
0.012368 \\
0.147007 \\
2882.040 \\
4.451749 \\
0.000187\end{array}$ & $\begin{array}{l}\text { Mean depeno } \\
\text { S.D. depende } \\
\text { Akaike info cr } \\
\text { Schwarz crite } \\
\text { Hannan-Quir } \\
\text { Durbin-Wats }\end{array}$ & $\begin{array}{l}\text { ent var } \\
\text { t var } \\
\text { erion } \\
\text { on } \\
\text { criter. } \\
\text { n stat }\end{array}$ & $\begin{array}{r}-6.08 \mathrm{E}-19 \\
0.012500 \\
-5.940166 \\
-5.904911 \\
-5.926746 \\
1.988019\end{array}$ \\
\hline
\end{tabular}

\section{Output Model}

\begin{tabular}{|lllll|}
\hline $\begin{array}{l}\text { Dependent Variable: RETURN } \\
\text { Method: Least Squares }\end{array}$ & & & \\
Date: 02/11/20 Time: 14:23 & & & \\
Sample: 1968 & & & & \\
Included observations: 968 & & & & \\
\hline \hline \multicolumn{6}{c}{ Variable } & Coefficient & Std. Error & t-Statistic & Prob. \\
\hline \hline C & 0.000790 & 0.000897 & 0.881128 & 0.3785 \\
SENIN & -0.002250 & 0.001280 & -1.757189 & 0.0792 \\
SELASA & 0.001199 & 0.001262 & 0.950090 & 0.3423 \\
RABU & 0.002158 & 0.001262 & 1.709630 & 0.0877 \\
JUMAT & 0.002753 & 0.001282 & 2.147316 & 0.0320 \\
\hline \hline R-squared & 0.019373 & Mean dependent var & 0.001575 \\
Adjusted R-squared & 0.015300 & S.D. dependent var & 0.012623 \\
S.E. of regression & 0.012526 & Akaike info criterion & -5.916883 \\
Sum squared resid & 0.151093 & Schwarz criterion & -5.891701 \\
Log likelihood & 2868.771 & Hannan-Quinn criter. & -5.907297 \\
F-statistic & 4.756211 & Durbin-Watson stat & 1.707393 \\
Prob(F-statistic) & 0.000838 & & & \\
\hline
\end{tabular}

\section{Uji Asumsi Klasik Pascakrisis 2007-2008}




\section{6 | Bina Ekonomi}

1. Uji Normalitas

\begin{tabular}{|lr|}
\hline \multicolumn{2}{|l|}{ Series: Residuals } \\
Sample 1979 \\
Obsenations 979 \\
Mean & $3.38 \mathrm{e}-19$ \\
Median & 0.000575 \\
Maximum & 0.069219 \\
Minimum & -0.089230 \\
Std. Dev. & 0.013109 \\
Skevuness & -0.160857 \\
Kurtosis & 7.664236 \\
& \\
Jarque-Bera & 891.6488 \\
Probability & 0.000000 \\
\hline
\end{tabular}

2. Uji Multikolinearitas

\begin{tabular}{|crrrr|}
\hline & SENIN & \multicolumn{1}{c}{ SELASA } & \multicolumn{1}{c}{ RABU } & \multicolumn{1}{c|}{ JUMAT } \\
\hline \hline SENIN & 1.000000 & -0.251111 & -0.252700 & -0.244736 \\
SELASA & -0.251111 & 1.000000 & -0.255125 & -0.247084 \\
RABU & -0.252700 & -0.255125 & 1.000000 & -0.248648 \\
JUMAT & -0.244736 & -0.247084 & -0.248648 & 1.000000 \\
\hline
\end{tabular}

3. Uji Heteroskedastisitas

Heteroskedasticity Test: White

Null hypothesis: Homoskedasticity

\begin{tabular}{llll}
\hline \hline F-statistic & 1.203966 & Prob. F $(4,974)$ & 0.3075 \\
Obs*R-squared & 4.816771 & Prob. Chi-Square(4) & 0.3066 \\
Scaled explained SS & 15.88653 & Prob. Chi-Square(4) & 0.0032 \\
\hline \hline
\end{tabular}

Test Equation:

Dependent Variable: RESID ${ }^{\wedge} 2$

Method: Least Squares

Date: 02/11/20 Time: $14: 30$

Sample: 1979

Included observations: 979

\begin{tabular}{|c|c|c|c|c|}
\hline Variable & Coefficient & Std. Error & t-Statistic & Prob. \\
\hline c & 0.000184 & 3.17E-05 & 5.823047 & 0.0000 \\
\hline SENIN"n2 & $3.35 \mathrm{E}-05$ & $4.48 \mathrm{E}-05$ & 0.748109 & 0.4546 \\
\hline SELASAn2 2 & $-3.31 E-05$ & $4.47 E-05$ & -0.741528 & 0.4586 \\
\hline $\mathrm{RABU}_{2}$ & $-5.98 E-06$ & $4.45 E-05$ & -0.134303 & 0.8932 \\
\hline JUMAT² & $-5.89 E-05$ & $4.51 \mathrm{E}-05$ & -1.305863 & 0.1919 \\
\hline R-squared & 0.004920 & \multicolumn{2}{|c|}{ Mean dependent var } & 0.000172 \\
\hline Adjusted R-squared & 0.000834 & \multicolumn{2}{|c|}{ S.D. dependent var } & 0.000443 \\
\hline S.E. of regression & 0.000443 & \multicolumn{2}{|c|}{ Akaike info criterion } & -12.60001 \\
\hline Sum squared resid & 0.000191 & \multicolumn{2}{|c|}{ Schwarz criterion } & -12.57505 \\
\hline Log likelihood & 6172.703 & \multicolumn{2}{|c|}{ Hannan-Quinn criter. } & -12.59051 \\
\hline F-statistic & 1.203966 & \multicolumn{2}{|c|}{ Durbin-Watson stat } & 1.726449 \\
\hline Prob(F-statistic) & 0.307471 & & & \\
\hline
\end{tabular}

4. Uji Autokorelasi 


\begin{tabular}{|c|c|c|c|c|}
\hline \multicolumn{5}{|c|}{$\begin{array}{l}\text { Breusch-Godfrey Serial Correlation LM Test: } \\
\text { Null hypothesis: No serial correlation at up to } 2 \text { lags }\end{array}$} \\
\hline $\begin{array}{l}\text { F-statistic } \\
\text { Obs*R-squared }\end{array}$ & $\begin{array}{l}0.341666 \\
0.687769\end{array}$ & \multicolumn{2}{|c|}{ Prob. $F(2,972)$} & $\begin{array}{l}0.7107 \\
0.7090\end{array}$ \\
\hline \multicolumn{5}{|c|}{$\begin{array}{l}\text { Test Equation: } \\
\text { Dependent Variable: RESID } \\
\text { Method: Least Squares } \\
\text { Date: } 02 / 11 / 20 \text { Time: } 14: 31 \\
\text { Sample: } 1979 \\
\text { Included observations: } 979 \\
\text { Presample missing value lagged residuals set to zero. }\end{array}$} \\
\hline Variable & Coefficient & Std. Error & t-Statistic & Prob. \\
\hline $\begin{array}{c}\text { C } \\
\text { SENIN } \\
\text { SELASA } \\
\text { RABU } \\
\text { JUMAT } \\
\text { RESID(-1) } \\
\text { RESID(-2) }\end{array}$ & $\begin{array}{r}9.07 \mathrm{E}-06 \\
-1.45 \mathrm{E}-05 \\
-7.55 \mathrm{E}-06 \\
-5.16 \mathrm{E}-06 \\
-1.73 \mathrm{E}-05 \\
0.004011 \\
0.026192\end{array}$ & $\begin{array}{l}0.000939 \\
0.001330 \\
0.001325 \\
0.001321 \\
0.001339 \\
0.032073 \\
0.032075\end{array}$ & $\begin{array}{r}0.009663 \\
-0.010914 \\
-0.005702 \\
-0.003907 \\
-0.012955 \\
0.125045 \\
0.816584\end{array}$ & $\begin{array}{l}0.9923 \\
0.9913 \\
0.9955 \\
0.9969 \\
0.9897 \\
0.9005 \\
0.4144\end{array}$ \\
\hline $\begin{array}{l}\text { R-squared } \\
\text { Adjusted R-squared } \\
\text { S.E. of regression } \\
\text { Sum squared resid } \\
\text { Log likelihood } \\
\text { F-statistic } \\
\text { Prob(F-statistic) }\end{array}$ & $\begin{array}{r}0.000703 \\
-0.005466 \\
0.013145 \\
0.167943 \\
2855.149 \\
0.113889 \\
0.994820\end{array}$ & \multicolumn{2}{|c|}{$\begin{array}{l}\text { Mean dependent var } \\
\text { S.D. dependent var } \\
\text { Akaike info criterion } \\
\text { Schwarz criterion } \\
\text { Hannan-Quinn criter. } \\
\text { Durbin-Watson stat }\end{array}$} & $\begin{array}{r}3.38 \mathrm{E}-19 \\
0.013109 \\
-5.818486 \\
-5.783546 \\
-5.805193 \\
1.972678\end{array}$ \\
\hline
\end{tabular}

\section{Output Model}

\begin{tabular}{|lllll|}
\hline $\begin{array}{l}\text { Dependent Variable: RETURN } \\
\text { Method: Least Squares }\end{array}$ & & & \\
Date: 02/11/20 Time: 14:30 & & & & \\
Sample: 1979 \\
Included observations: 979 & & & \\
\hline \hline \multicolumn{1}{c}{ Variable } & Coefficient & Std. Error & t-Statistic & Prob. \\
\hline \hline C & 0.000427 & 0.000938 & 0.454725 & 0.6494 \\
SENIN & -0.000863 & 0.001329 & -0.649312 & 0.5163 \\
SELASA & 0.000954 & 0.001324 & 0.721042 & 0.4711 \\
RABU & 0.003008 & 0.001320 & 2.278427 & 0.0229 \\
JUMAT & 0.001073 & 0.001337 & 0.802688 & 0.4224 \\
\hline \hline R-squared & 0.009761 & Mean dependent var & 0.001271 \\
Adjusted R-squared & 0.005695 & S.D. dependent var & 0.013173 \\
S.E. of regression & 0.013136 & Akaike info criterion & -5.821869 \\
Sum squared resid & 0.168061 & Schwarz criterion & -5.796912 \\
Log likelihood & 2854.805 & Hannan-Quinn criter. & -5.812374 \\
F-statistic & 2.400352 & Durbin-Watson stat & 1.969442 \\
Prob(F-statistic) & 0.048445 & & & \\
\hline \hline
\end{tabular}

